\title{
Lower Cretaceous (Hauterivian-Albian) ammonite biostratigraphy in the Maestrat Basin (E Spain)
}

\author{
R. Garcia1 ${ }^{1}$, J.A. Moreno-Bedmar*2, T. Bover-Arnal ${ }^{3}$, M. Company ${ }^{4}$, R. Salas 3 , J-L. Latil5, J.D. \\ Martín-Martín ${ }^{4}$, E. Gomez-Rivas ${ }^{6}$, L.G. Bulot ${ }^{7}$, G. Delanoy ${ }^{8}$, R. Martínez ${ }^{9}$, A. Grauges ${ }^{9}$ \\ ${ }^{1}$ Av. Josep Tarradelles i Joan 14 bxs. $4^{a}$, 08870, Sitges, Barcelona, Spain. \\ ${ }^{2}$ Departamento de Paleontología, Instituto de Geología, Universidad Nacional Autónoma de México, Ciudad Universitaria, \\ Delegación Coyoacán, 04510, México, D.F., Mexico. \\ ${ }^{3}$ Departamento de Estratigrafía y Paleontología, Facultad de Ciencias, Universidad de Granada, 18002 Granada, Spain. \\ ${ }^{4}$ Departament de Geoquímica, Petrologia i Prospecció Geologica, Universitat de Barcelona, 08028 Barcelona, Spain. \\ ${ }^{5}$ Le Maupas, F-05300 Lazer, France \\ ${ }^{6}$ Department of Geosciences, Eberhard Karls Universität Tübingen, Wilhelmstrasse 56, 72074 Tübingen, Germany. \\ ${ }^{7}$ FRE CNRS 2761, Géologie des Systèmes Carbonatés, Université de Provence, F-13331 Marseille Cedex, France. \\ ${ }^{8}$ Département des Sciences de la Terre, Université de Nice-Sophia Antipolis. 28 Avenue Valrose F-06100 Nice, France. \\ ${ }^{9}$ Departament de Geologia. Universitat Autònoma de Barcelona. Edifici C. 08193-Bellaterra, Barcelona, Spain. \\ e-mail addresses: ruben jsc@hotmail.com (R.G.); josepamb@geologia.unam.mx (J.A.M.-B., *corresponding author); telm.boverarnal@adelaide.edu.au (T.B.-A.); \\ mcompany@ugr.es (M.C.); ramonsalas@ub.edu (R.S.); g.r.e.g.b@wanadoo.fr (J.L.-L.); juandiegomartin@ub.edu (J.D.M.-M.); enrique@gomez-rivas.info \\ (E.G.-R.);LucGBulot@aol.com (L.G.B.); gerard.delanoy06@orange.fr (G.D.);Ricard.Martinez@uab.cat (R.M.); antonigrauges@hotmail.com (A.G.)
}

Received: 3 September 2012 / Accepted: 4 December 2013 / Available online: 25 February 2014

\begin{abstract}
A review of the stratigraphic distribution of ammonoid species in the Lower Cretaceous (Hauterivian-Albian) of the Maestrat Basin (E Spain) was carried out. The specimens were mainly collected in the field by us and are stored in university or museum collections. Specimens from private collections and figured in the literature were also studied. We recognized 73 species that are distributed, in accordance with the latest version of the standard Mediterranean ammonite zonation for the Lower Cretaceous, in 14 ammonite zones: Acanthodiscus radiatus, Crioceratites loryi, Lyticoceras nodosoplicatum (Lower Hauterivian); Pseudothurmannia ohmi (Upper Hauterivian); Imerites giraudi (Upper Barremian); Deshayesites oglanlensis, Deshayesites forbesi, Deshayesites deshayesi, Dufrenoyia furcata (Lower Aptian); Epicheloniceras martini, Parahoplites melchioris, Acanthohoplites nolani (Upper Aptian); Leymeriella tardefurcata and Douvilleiceras mammillatum (Lower Albian). The recognition of these biozones allows a precise age calibration of the Maestrat Basin's lithostatigraphic units that contain ammonoids as well as an associated indirect age calibration of the formations without ammonoids. Consequently, this report provides an updated, comprehensive and precise biostratigraphic framework, which aims to become a reference for the analysis of the Lower Cretaceous strata of the Maestrat Basin. The results are also relevant for the analysis of coeval ammonite-bearing sedimentary successions found in other Tethyan basins.
\end{abstract}

Keywords: ammonites, Lower Cretaceous, biostratigraphy, Maestrat Basin, Spain

\section{Resumen}

En este trabajo se ha realizado una revisión detallada de la distribución estratigráfica de las especies de ammonoideos del Cretácico inferior de la Cuenca del Maestrazgo (Este de España). Los ejemplares recolectados, principalmente por los autores, han sido depositados en colecciones universitarias y museísticas. Además hemos estudiado los ejemplares de colecciones privadas y figurados en la literatura. Hemos reconocido 73 especies que se distribuyen, siguiendo la última versión de la biozonación de ammonites mediterránea estándar del Cretácico inferior, en 14 zonas de ammonoideos: Acanthodiscus radiatus, Crioceratites loryi, Lyticoceras nodosoplicatum (Hauteriviense inferior); Pseudothurmannia ohmi (Hauteriviense superior); Imerites giraudi (Barremiense superior); Deshayesites oglanlensis, Deshayesites forbesi, Deshayesites deshayesi, Dufrenoyia furcata (Aptiense inferior); Epicheloniceras martini, Parahoplites melchioris, Acanthohoplites nolani (Aptiense superior); Leymeriella tardefurcata y Douvilleiceras mammillatum (Albiense inferior). El reconocimiento de estas biozonas permite precisar la edad de las unidades litoestratigráficas que contienen ammonites y también una calibración indirecta de las formaciones que no contienen ammonites. En consecuencia este trabajo proporciona un marco bioestratigráfico actualizado, exhaustivo y preciso que pretende ser una referencia para el análisis estratigráfico del Cretácico inferior de la Cuenca del Maestrazgo. Los resultados obtenidos son también relevantes para el análisis de las sucesiones sedimentarias coetáneas con ammonites existentes en otras cuencas de Tetis. 


\section{Introduction}

The presence of Lower Cretaceous ammonoids in the Maestrat Basin (E Spain) has been known since the second half of the nineteenth century (e.g., Vilanova, 1859; Coquand, 1865). There are many works, meeting abstracts, and doctoral theses that are focused on and/or contain data of this ammonoid record. However, the literature remains dispersed and difficult to access. Many studies are outdated because ammonoid biostratigraphic knowledge is continually improving, as indicated in the numerous reports from other Lower Cretaceous localities of the Tethys (e.g., Cecca et al., 1999; Avram, 1999; Delanoy, 1995; Dutour, 2005; Ropolo et al., 2000; Aguado et al., 1997; Moreno-Bedmar et al. 2009a, 2010a; Najarro et al., 2011; Moreno-Bedmar et al., 2012a), as well as in the subsequent versions of the standard Mediterranean zonation published during the last two decades (Hoedemaeker and Bulot, 1990; Hoedemaeker et al., 1993; Hoedemaeker et al., 1995; Rawson et al., 1999; Hoedemaeker et al., 2000; Hoedemaeker et al., 2003; Reboulet et al., 2006; Reboulet et al., 2009, Reboulet et al., 2011). The stratigraphic knowledge and understanding of the Lower Cretaceous of the Maestrat Basin has also evolved and improved in recent years (e.g., Salas et al., 2001; Bover-Arnal et al., 2010).

In the present work, we update and review the biostragraphic ammonoid knowledge of this basin following the latest version of the standard Mediterranean ammonite zonation (Reboulet et al., 2011). The ammonite zonation in Mesozoic sedimentary successions is the most useful biostratigraphic tool as it supplies the most precise zonation. Therefore, this study also provides a reference for the analysis of coeval ammonite-bearing successions found in other basins of the Tethys.

\section{Geological setting}

The Maestrat Basin is located at the eastern Iberian Peninsula (Fig. 1). It corresponds to an intraplate rift basin, which developed during the Late Oxfordian-early Late Albian as a result of the spreading Atlantic Ocean and the opening of the Bay of Biscay (Salas \& Casas, 1993; Salas et al., 2001). The rift stage structured the Maestrat Basin into 7 sub-basins: Galve, Aliaga, Oliete, Morella, El Perelló, Salzedella and Penyagolosa (Fig. 1) (Salas and Guimerà, 1996). During this time, a sedimentary succession of up to $>2500 \mathrm{~m}$ thick made up of continental to hemipelagic deposits accumulated (e.g., Canérot et al., 1982). The depocenter of the basin was located at the Salzedella Sub-basin (Fig. 1). During the Paleogene the Alpine orogeny caused the inversion of the Iberian Mesozoic rifts, and the Maestrat Basin gave rise to the eastern part of the Iberian Chain (Salas and Casas, 1993; Salas et al., 2001).

The ammonite biostratigraphic analysis reported in this study is focused on the Hauterivian to Albian stages (Lower Cretaceous). Ammonites occur within 8 lithostratigraphic units named, from older to younger: Gaita Formation (Hauterivian), Morella Formation (Barremian? Aptian?), Forcall Formation (Aptian), Villarroya de los Pinares Formation (Aptian), Benassal Formation (Aptian), Dehesa Formation (Aptian), Escucha Formation (Albian) and an Albian unit of green marls lacking a formal name (Figs. 2 and 3).

The Gaita Formation is constituted by a hemipelagic succession of marls and limestones (Salas, 1987). The Morella Formation is made up of fluviatile sandstones and red clays, which were occasionally influenced by tides (e.g., Canérot et al., 1982). This formation is characterized by the presence of dinosaur remains. The Forcall Formation corresponds to a succession of marls, marly limestones and limestones. This is the most prolific formation in terms of ammonoid content of all the lithostratigraphic units studied (e.g., Moreno-Bedmar et al., 2010a). Other macrofossils present, or locally characteristic, within this formation are orbitolinids, nautiloids, brachiopods, vermetid gastropods, solitary corals, serpulids, echinoids, Plicatula placunea and Lithocodium aggregatum (e.g., Bover-Arnal et al., 2010; 2011). The Villarroya de los Pinares Formation is mainly made up of platform top carbonates, which change laterally to slope facies exhibiting marllimestone alternations (Bover-Arnal et al., 2009). Characteristic fossil content found within this formation include corals, Chondrodonta and rudists such as Toucasia carinata, Caprina parvula and Polyconites hadriani (e.g., Bover-Arnal et al., 2010; Skelton et al., 2010). The Benassal Formation is primarly formed by very-shallow marine to transitional alternations of clays, marls, marly limestones and limestones. Common skeletal components are orbitolinids and shells of Toucasia sp., nerineid gastropods and brachiopods (e.g., Canérot et al., 1982; Bover-Arnal et al., 2010). The Dehesa Formation is made up of a succession of marls and skeletal limestones. This formation is the lateral equivalent of the Benassal Formation in the Oliete Sub-basin (Canérot et al., 1982). The Escucha Formation mainly comprises a succession of continental clays, sandstones and coal. However, its base, where the ammonites occur, presents a transgressive interval with marine calcarenitic limestones and marls (Canérot et al., 1982; Moreno-Bedmar et al., 2008). The Albian informal unit of green marls analysed corresponds to transitional deposits stratigraphically located between the fluvial sandstones of the Utrillas Formation and the marine limestones and marls of the Mosqueruela Formation (Canérot et al., 1982).

\section{Material}

This study is mainly based on more than 3000 specimens of ammonites collected during the last 30 years from numerous Lower Cretaceous outcrops in the Maestrat Basin (Fig. 1). The localities sampled are the following. In the Salzedella Sub-basin: La Torre d'en Doménec section (Moreno et al., 2007), the area of Traiguera (Moreno-Bedmar et al., 2008), and in the environs of the village of Sant Mateu, we stud- 


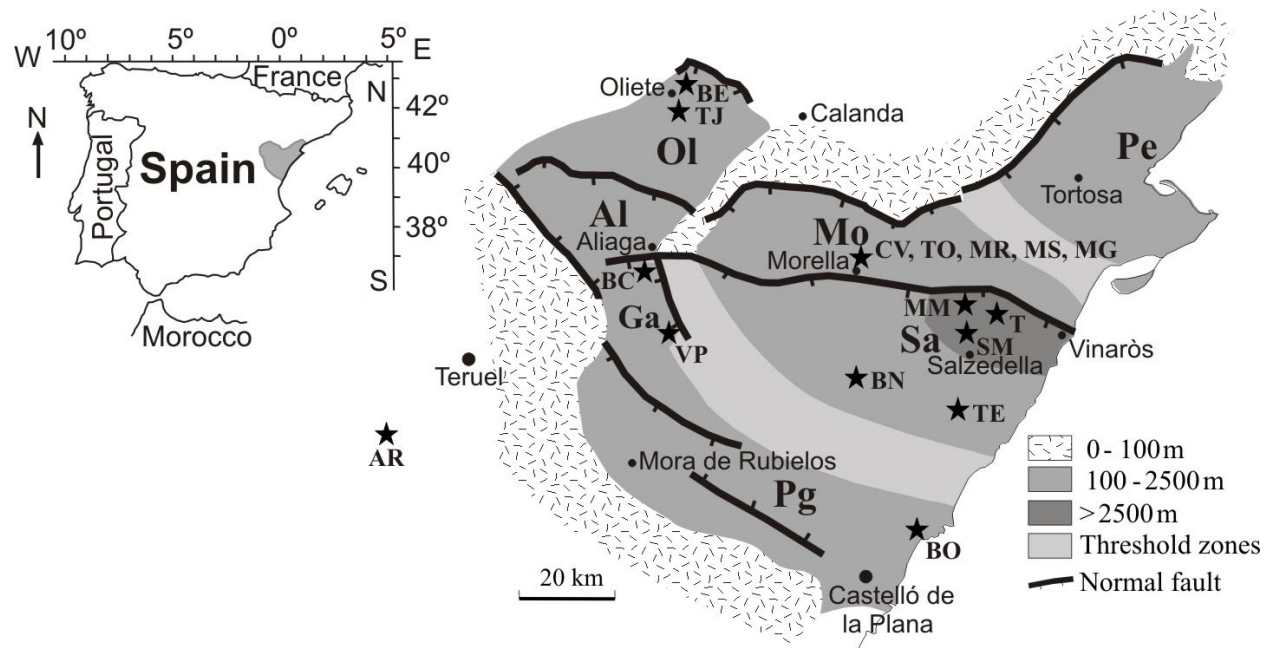

Fig. 1.- Simplified paleogeographic map of the Maestrat Basin during the Early Cretaceous (modified after Salas et al. 2001), showing the location of the sections and studied areas. TE: La Torre d'en Doménec section; SM: San Mateu area; T: Traiguera area; MM: Mola Murada section; BO: Benicàssim-Orpesa area; BN: Benassal area; BC: Barranco de las Calzadas section; VP: Villarroya de los Pinares section; CV: Cap de Vinyet section; TO: Todolella section; MR: Mas del Roc section; MS: Mas Segura section; TJ: Tejería de Josa section, BE: Barranco Emilia section; AR: Arroyofrío area; Ol: Oliete Sub-basin; Al: Aliaga Sub-basin; Mo: Morella Sub-basin; Pe: Perelló Sub-basin; Ga: Galve Sub-basin; Sa: Salzedella Sub-basin; Pg: Penyagolosa Sub-basin.

ied Les Bassetes del Cocó de l'Estaca and La Gaita sections (Tomás, 2007). In the Penyagolosa Sub-basin: the Cingle del Morral section and La Ferradura area (Benicàssim-Orpesa area; Moreno-Bedmar et al., 2009b), and the surroundings of Xodos and Benassal. In the Galve Sub-basin: the Barranco de las Calzadas and Villarroya de los Pinares sections (Bover-Arnal et al., 2010 and Moreno-Bedmar et al., 2010a). In the Morella Sub-basin: the Mola Garumba area, and the sections of Cap de Vinyet, Todolella, Mas del Roc and Mas Segura (Moreno-Bedmar et al., 2010a). In Oliete Sub-basin: the Tejería de Josa and Barranco Emilia sections (MorenoBedmar et al., 2010a). In the south of l'Espadà we studied the area of Arroyofrío (Geyer, 1995a, b).

The ammonoids studied were deposited in museums $(\mathrm{Mu}-$ seu de Valltorta: MV, València; Conjunto Paleontológico de Teruel: CPT, Aragón) or in university collections (Colleccions de Paleontologia de la Universitat Autònoma de Barcelona: PUAB, Bellaterra, Catalunya). We also studied ammonoids from private and museum collections (Museu Paleontològic Juan Cano Forner in Sant Mateu; Rafael Martí: RM, Andrés Cumba: AC and Domingo Tolós: DT in La Jana, València; Museu Geològic del Seminari Conciliar de Barcelona: MGSB, Barcelona). Finally, ammonoids figured in the literature were also analyzed.

\section{Ammonite biostratigraphy}

Ammonoids are generally rare and sparsely distributed throughout the Lower Cretaceous succession of the Maestrat Basin. Only few individual beds or marly intervals yielded abundant material. However, the large time span comprised by the ammonoid collection allows us to present a very complete record.

\subsection{Lower Hauterivian}

Few works quote ammonoids of this age, all of which were found in the Salzedella Sub-basin (Fig. 1). Canérot (1974) listed some species from the environs of the village of Sant Mateu, La Torre d'en Besora and Massís de la Serratella localities. Neumann (1987) identified some ammonoids of the Acanthodiscus radiatus Zone in La Torre d'en Doménec and others from the Lower Hauterivian of La Torre d'en Besora. In La Torre d'en Doménec, Moreno et al. (2007) identified two biozones: Acanthodiscus radiatus and Crioceratites loryi. In the present work, we recognized all the ammonite zones of the Lower Hauterivian (Fig. 2).

Acanthodiscus radiatus Zone. This zone has been recognized by the occurrence of Breistrofferella cf. castellanensis (d'Orbigny) in La Torre d'en Doménec. (Fig. 4 E).

Crioceratites loryi Zone. Also in La Torre d'en Doménec, we have found Olcostephanus (Jeannoticeras) jeannoti (d'Orbigny) and Olcostephanus sayni (Kilian) (Fig. 4 H) species that characterize the Crioceratites loryi Zone. In particular, O. jeannoti is currently used to define its upper subzone.

Lyticoceras nodosoplicatum Zone. In the same locality, this zone is represented by the index taxa Lyticoceras nodosoplicatum (Kilian and Reboulet) (Fig. 4 A-B, F-G, I) and Lyticoceras kiliani Reboulet and Atrops (Fig. 4 C-D).

\subsection{Upper Hauterivian}

The ammonoids of this age come from the Salzedella Subbasin as well (Fig. 1). Canérot (1974) listed some species from La Torre d'en Besora. Neumann (1987) reported some ammonites from the Tossal d'Orenga and assigned them to the Plesiospitidiscus ligatus and Balearites balearis Zones. 
Salzedella Sub-basin

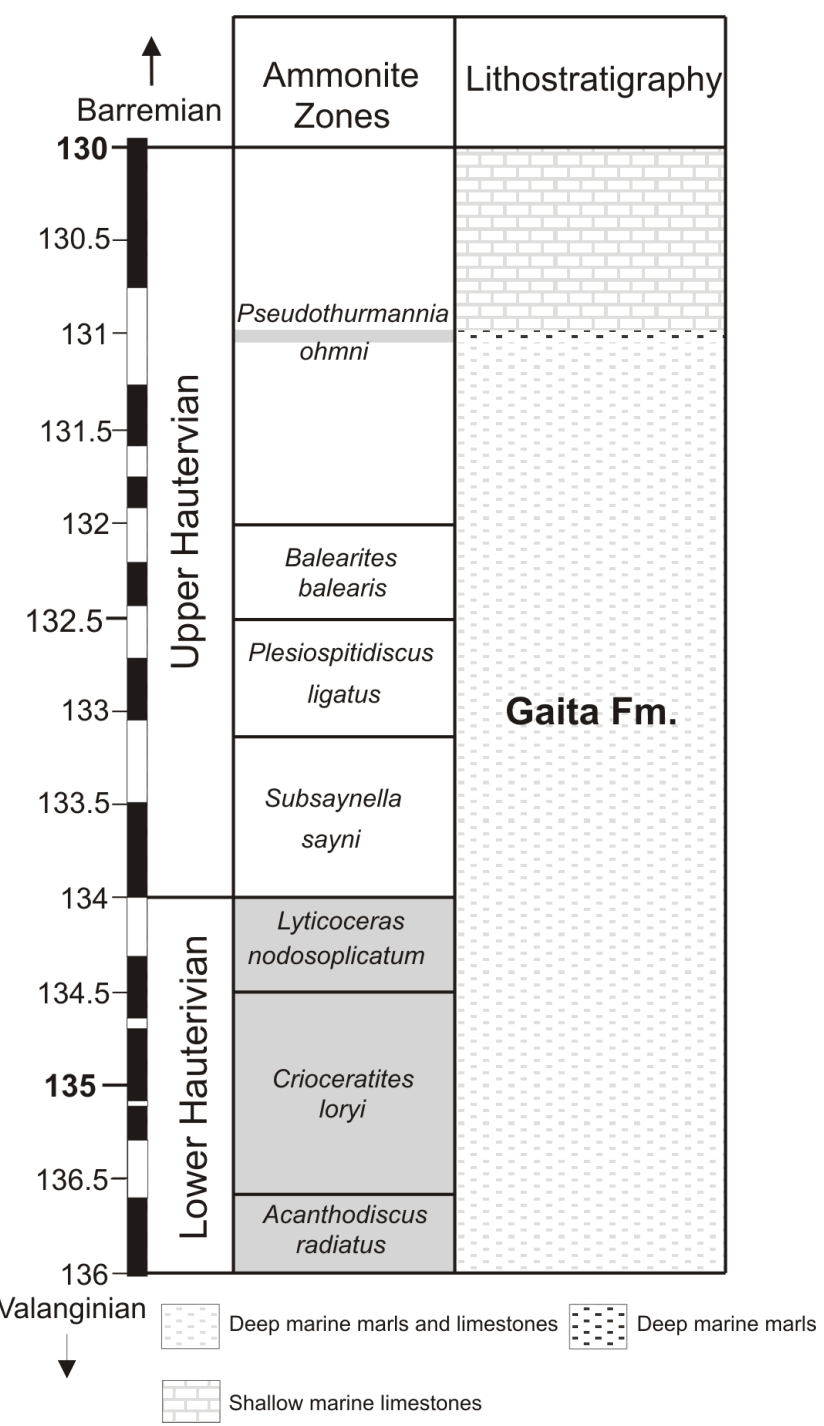

Fig. 2.- Chronostratigraphy of the Hauterivian deposits in the Salzedella Sub-basin (Maestrat Basin). The ammonite zones recognized are indicated by the shaded levels. Absolute ages after Gradstein et al. (2004).

Martínez et al. (1994) studied the ammonoid record of the Les Bassetes del Cocó de l'Estaca and also recognized the Plesiospitidiscus ligatus and Balearites balearis Zones. They also reported one specimen of the Castellfort-Coll d'Ares that they attributed to the species Crioceratites (Pseudothurmania) grandis, from the Pseudothumannia angulicostata Zone (=Pseudothumannia ohmi Zone of Reboulet et al., 2011).

Pseudothumannia ohmi Zone. In this work we have studied an interesting pyritized fauna coming from Les Bassetes del Cocó de l'Estaca, and La Gaita. We have identified: Barremites primitivus Cecca, Faraoni and Marini (Fig. 5 A-E, F, I-J, N-P), Plesiospitidiscus sp. (Fig. $5 \mathrm{~K}$ ) and Pseudothurmannia sp. (Fig. 5 G-H, L-M). This fauna probably indicates the middle-upper part of the zone (Pseudothumannia catulloi and/or Pseudothumannia picteti Subzones).

\subsection{Upper Barremian}

López Llorens (2007) reported the finding of a sole Barremian ammonite from the Morella Sub-basin, a juvenile heteroceratid that he attributed to the Imerites giraudi (Kilian). The revision of this specimen for the present work indicates that the determination was probably wrong and this ammonoid is most likely an Argvethites sp. The genus Argvethites sp. is present in the uppermost Barremian (Imerites giraudi Zone, spanning both the Imerites giraudi and the Martelites sarasini Subzones (Delanoy, 1997).

\subsection{Lower Aptian}

The Lower Aptian ammonite record is the best-known record in the Maestrat Basin (Moreno-Bedmar et al., 2010a). These authors recognized four zones and five subzones some of which are new, and were recently accepted and published in the biostratigraphic scheme of the latest standard Mediterranean zonation (Reboulet et al., 2011). More recently, studies such as Moreno-Bedmar and Garcia (2011) and Delanoy et al. (2013) have helped to complete the knowledge about the Lower Aptian ammonoid record.

Deshayesites oglanlensis Zone. Moreno-Bedmar et al. (2010a) and Moreno-Bedmar and Garcia (2011) identified the Deshayesites oglanlensis Zone and proposed a new Deshayesites luppovi Subzone in the Morella Sub-basin (Figs. 1 and 3). In this zone, the following species were recognized: Procheloniceras sp., Deshayesites antiquus Bogdanova (Fig. 6 A), Deshayesites luppovi Bogdanova (Fig. 6 B), and Deshayesites sp. cf. oglanlensis Bogdanova.

Deshayesites forbesi Zone. Moreno-Bedmar et al. (2010a) proposed the inclusion of this boreal zone in the Tethyan zonation. This zone was identified in the Oliete, Morella and Galve sub-basins (Fig. 1). They also proposed a Roloboceras hambrovi Subzone (Fig. 3). Recently, Grauges et al. (2010) studied the taxonomy of the Lower Aptian desmoceratid fauna (Pseudosaynella and Pseudohaploceras genera) of this zone in the Oliete Sub-basin. Moreno-Bedmar and Garcia (2011) provided new data from the ammonoid record on the lower part of this zone in the Morella Sub-basin through the collection of new specimens, including the best specimen of the index species known to date of this biozone, Deshayesites forbesi. The species recognized in this zone are: Pseudosaynella raresulcata (d'Orbigny) (= Pseudosaynella undulata (Sarasin), see Grauges et al., 2010, p. 9), Pseudosaynella bicurvata (Michelin), Pseudosaynella sp., Barremites sp., Pseudohaploceras liptoviense (Zeuschner), Pseudohaploceras sp., Toxoceratoides royerianus (d'Orbigny), Ancyloceras? sp., Proaustraliceras sp., Lithancylus cf. grandis (Sowerby), Cheloniceras sp., Roloboceras hambrovi (Forbes), Roloboceras hispanicum Sornay and Marin, Roloboceras sp., Megatyloceras coronatum (Rouchadzé), Megatyloceras transiens Casey, Deshayesites euglyphus Casey, Deshayesites gr. euglyphus/spathi Casey, Deshayesites forbesi Casey (Fig. 6 C-D), Deshayesites spathi Casey and Deshayesites sp. 

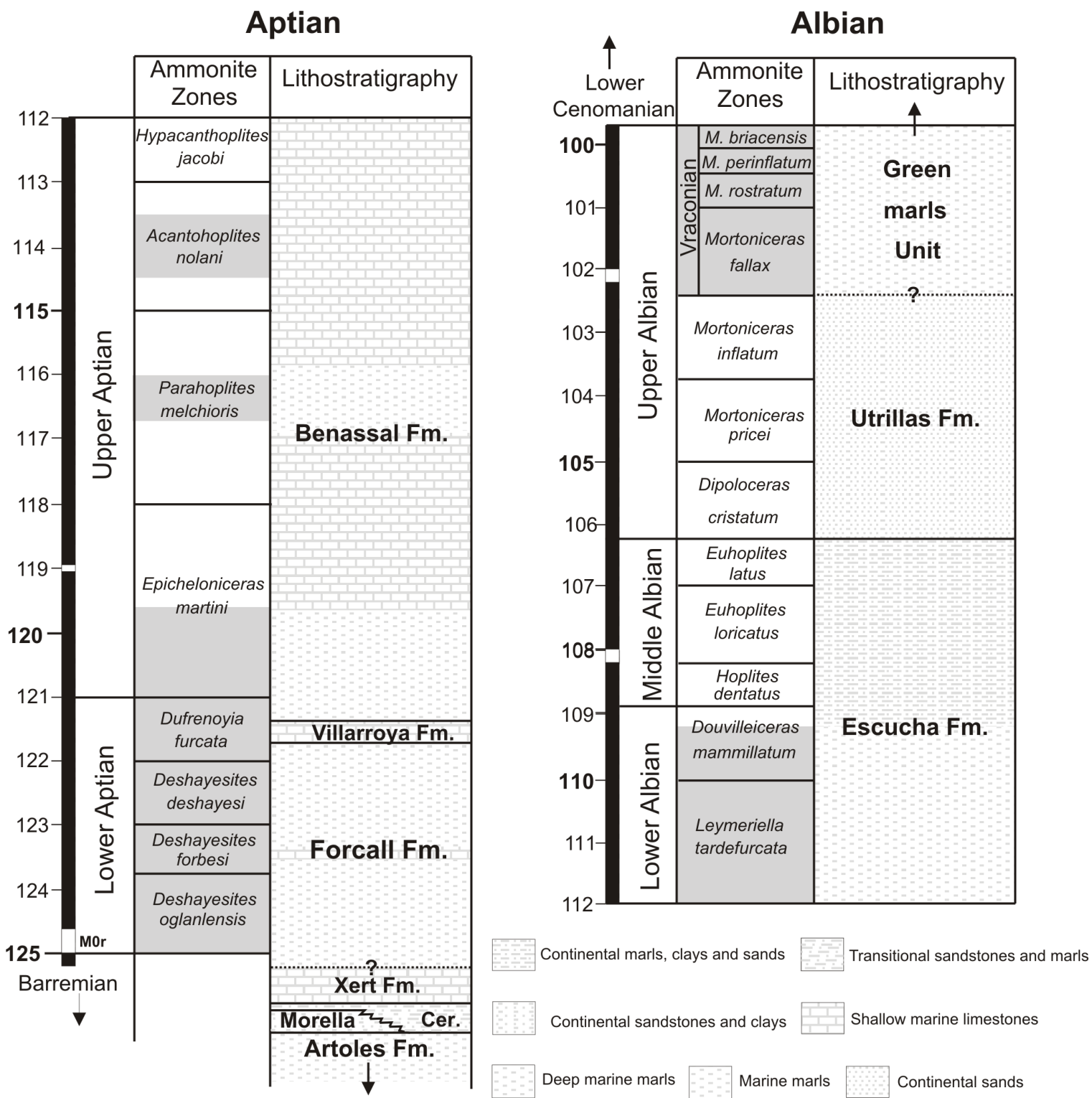

Fig. 3.- Chronostratigraphy of the Aptian-Albian deposits in the Maestrat Basin. The ammonite zones recognized are indicated by the shaded levels. Absolute ages after Gradstein et al. (2004).

Deshayesites deshayesi Zone. Moreno-Bedmar et al. (2010a) identified the Deshayesites deshayesi Zone and its Subzone, Deshayesites grandis, in the Morella, Galve, Salzedella and Penyagolosa sub-basins (Figs. 1 and 3). This zone contains the species: Phylloceras sp., Lytoceras belliseptatum, Anthula, Pseudosaynella raresulcata (d'Orbigny), Pseudosaynella bicurvata (Michelin), Pseudohaploceras sp., Ammonitoceras (Epancyloceras) sp., Proaustraliceras cf. gigas (Sowerby), Toxoceratoides royerianus (d'Orbigny), Cheloniceras cornuelianum (d'Orbigny), Deshayesites deshayesi (d'Orbigny) (Fig. 6 E-G), Deshayesites vectensis (Spath) (Fig. 6 H), Deshayesites latilobatus/involutus group, Deshayesites grandis (Spath) and Deshayesites sp. Recently a new genus and species was described in Salzedella Sub-basin, Xerticeras salasi Delanoy, Moreno-Bedmar, Ruiz, Tolós Lládser, 2013. This new taxon is present in Deshayesites deshayesi and Dufrenoya furcata zones.
Dufrenoyia furcata Zone. Moreno-Bedmar et al. (2010a, 2010b) identified this zone in the Perelló, Galve, Salzedella and Penyagolosa sub-basins (Fig. 1). They also recognized the two subzones proposed by Dutour (2005) in the Vocontian Basin (France): Dufrenoyia furcata and Dufrenoyia dufrenoyi. Moreno-Bedmar et al. (2010b) and Garcia and Moreno-Bedmar (2010) contributed to the knowledge of the Dufrenoyia furcata Zone in the Perello Sub-basin where they studied a rich record of pyritized ammonites. MorenoBedmar et al. (2011, 2012b) studied some species of the Dufrenoyia genus from the uppermost part of this zone in the Morella and Galve sub-basins. The following species were recognized in this zone: Phyllopachyceras baborense (Coquand), Salfeldiella sp., Pseudosaynella raresulcata (d'Orbigny), Pseudohaploceras sp., Macroscaphites striasulcatus (d'Orbigny), Aconeceras nisum (d'Orbigny), Cheloniceras cornuelianum (d'Orbigny), Dufrenoyia furcata 

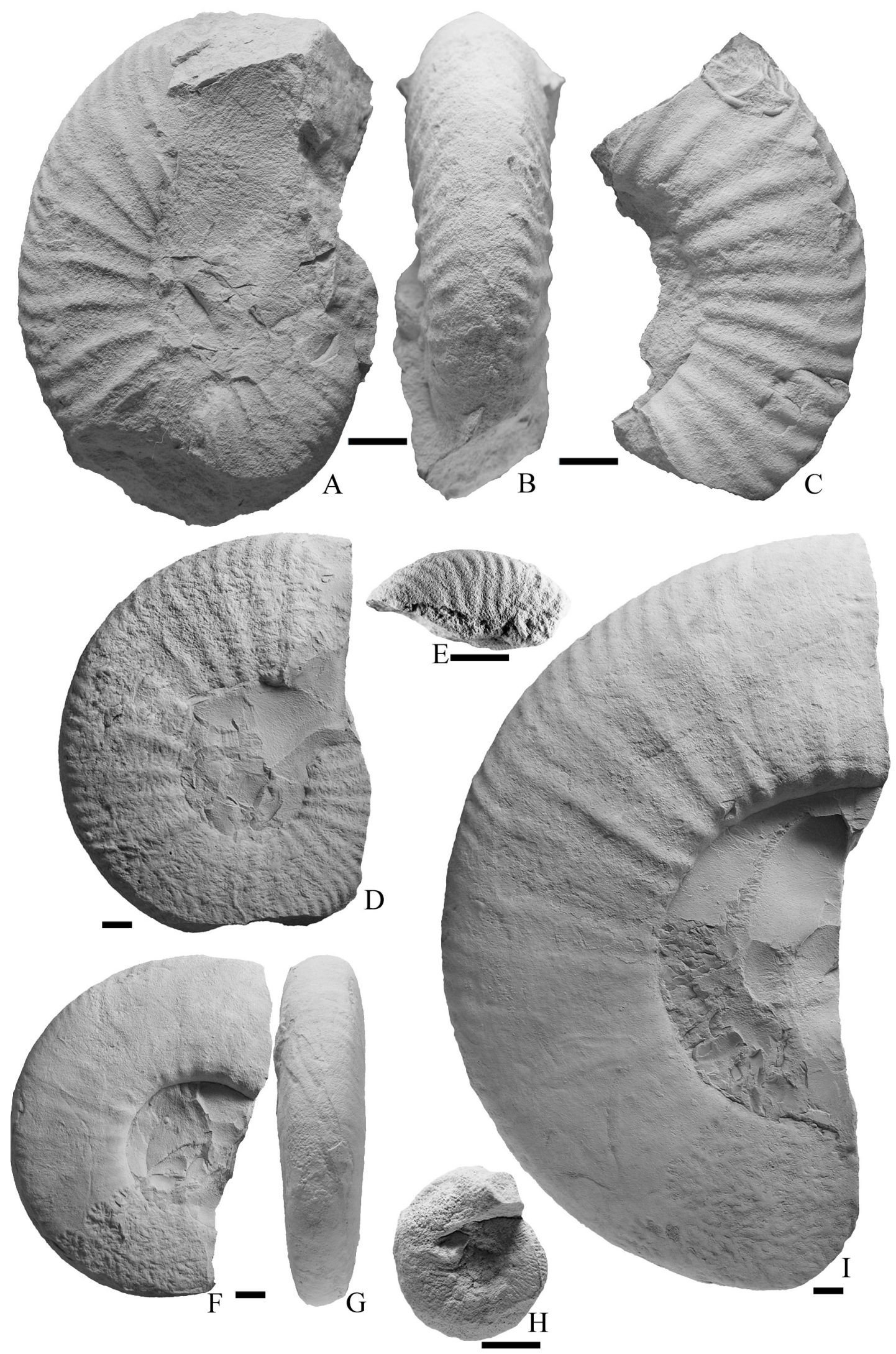

Fig. 4.- A-B: Lyticoceras nodosoplicatum lateral and ventral views of the specimen PUAB 88777, La Torre d'en Doménec. C: Lyticoceras kiliani lateral view of the specimen PUAB 88776, La Torre d'en Doménec. D: Lyticoceras kiliani lateral view of the specimen PUAB 88780, La Torre d'en Doménec. E: Breistrofferella cf. castellanensis lateral view of the specimen PUAB 48651, La Torre d'en Doménec. F-G: Lyticoceras nodosoplicatum lateral and ventral views of the specimen PUAB 88778, La Torre d'en Doménec. H: Olcostephanus sayni lateral view of the specimen PUAB 48650, La Torre d'en Doménec. I: Lyticoceras nodosoplicatum lateral view of the specimen PUAB 88781, La Torre d'en Doménec. Scale bar=10 $\mathrm{mm}$. 

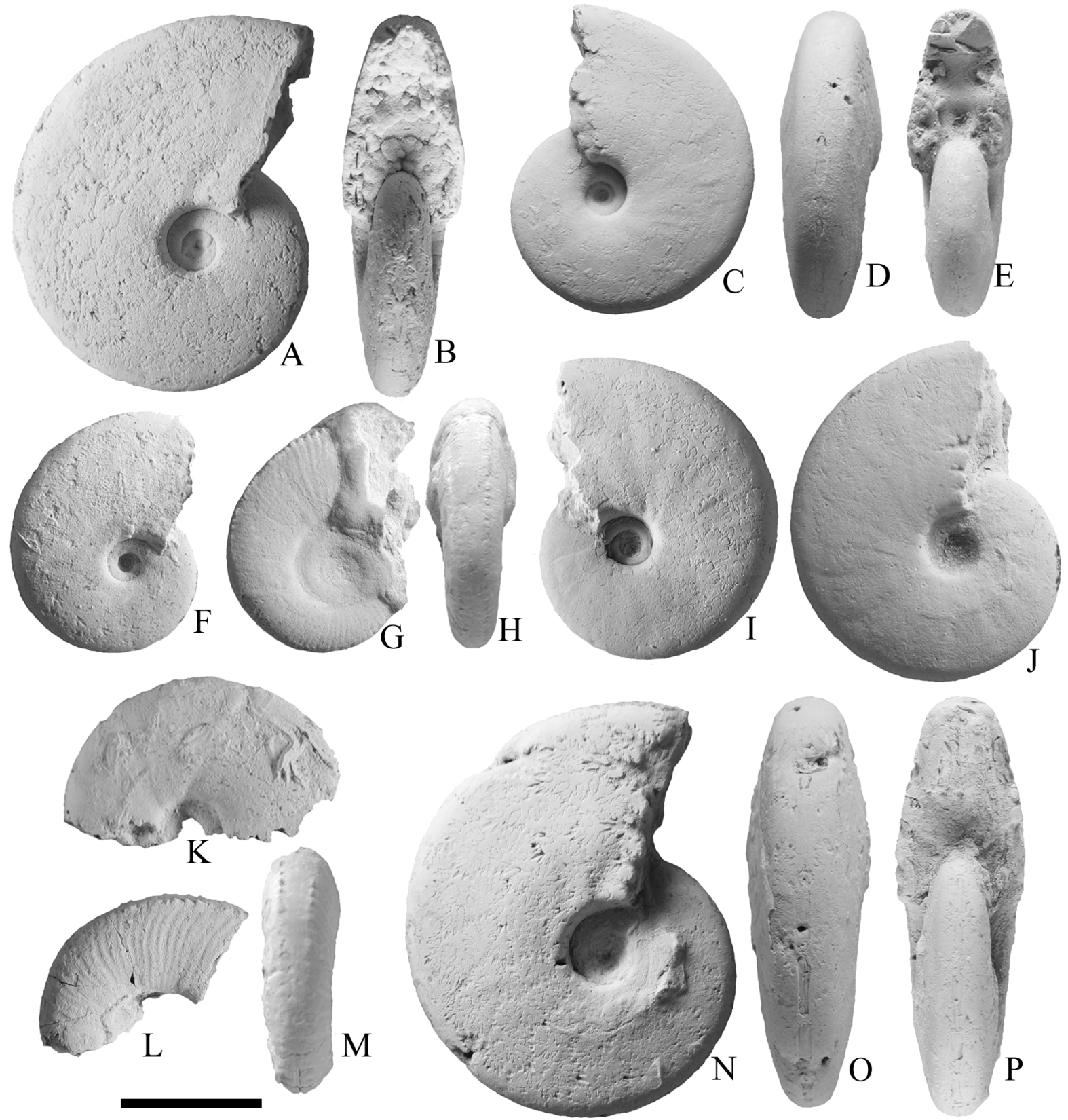

Fig. 5.- A-B: Barremites primitivus lateral and fontral views of the specimen PUAB 12533, La Gaita. C-E: Barremites primitivus lateral, ventral and frontal views of the specimen PUAB 12529, Les Bassetes del Cocó de l'Estaca. F: Barremites primitivus lateral view of the specimen PUAB 88798, La Gaita. G-H: Pseudothurmannia sp. juv. lateral and ventral views of the specimen PUAB 12530, Les Bassetes del Cocó de l'Estaca. I: Barremites primitivus lateral view of the specimen PUAB 88795, Les Bassetes del Cocó de l'Estaca. J: Barremites primitivus lateral view of the specimen PUAB 88794, Les Bassetes del Cocó de l'Estaca. K: Plesiospitidiscus sp. lateral and ventral views of the specimen PUAB 12530, Les Bassetes del Cocó de l'Estaca. L-M: Pseudothurmannia sp. juv. lateral and ventral views of the specimen PUAB 88790, Les Bassetes del Cocó de l'Estaca. N-P: Barremites primitivus lateral, ventral and frontal views of the specimen PUAB 88793, Les Bassetes del Cocó de l'Estaca. Scale bar=10 mm.

(Sowerby), Dufrenoyia cf. furcata (Sowerby) (Fig. 6 I-N), Dufrenoyia dufrenoyi (d'Orbigny), Dufrenoyia cf. dufrenoyi (d'Orbigny), Dufrenoyia cf. transitoria Casey, Dufrenoyia cf. justinae (Hill) (Fig. 6 O-P) and Colombiceras sp.

\subsection{Upper Aptian}

Epicheloniceras martini Zone. This zone has been identified only in the Benicàssim-Orpesa area, Penyagolosa Sub- basin (Fig. 1) (Moreno-Bedmar et al., 2009). The ammonites reported are: Caseyella sp. (Fig. 7 C), Colombiceras sp., Epicheloniceras sp. (Fig. 7 D-E) and Epicheloniceras cf. debile.

Parahoplites melchioris Zone. Ammonites characteristic of this zone have been cited in several previous papers. Sornay and Marin (1971) reported the occurrence of Acanthohoplites sp. and Parahoplites sp. from Cañizar del Olivar (Oliete Subbasin) and of Parahoplites cf. cunningtoni from Cantavieja (Galve Sub-basin). Martínez et al. (1994) identified the am- 

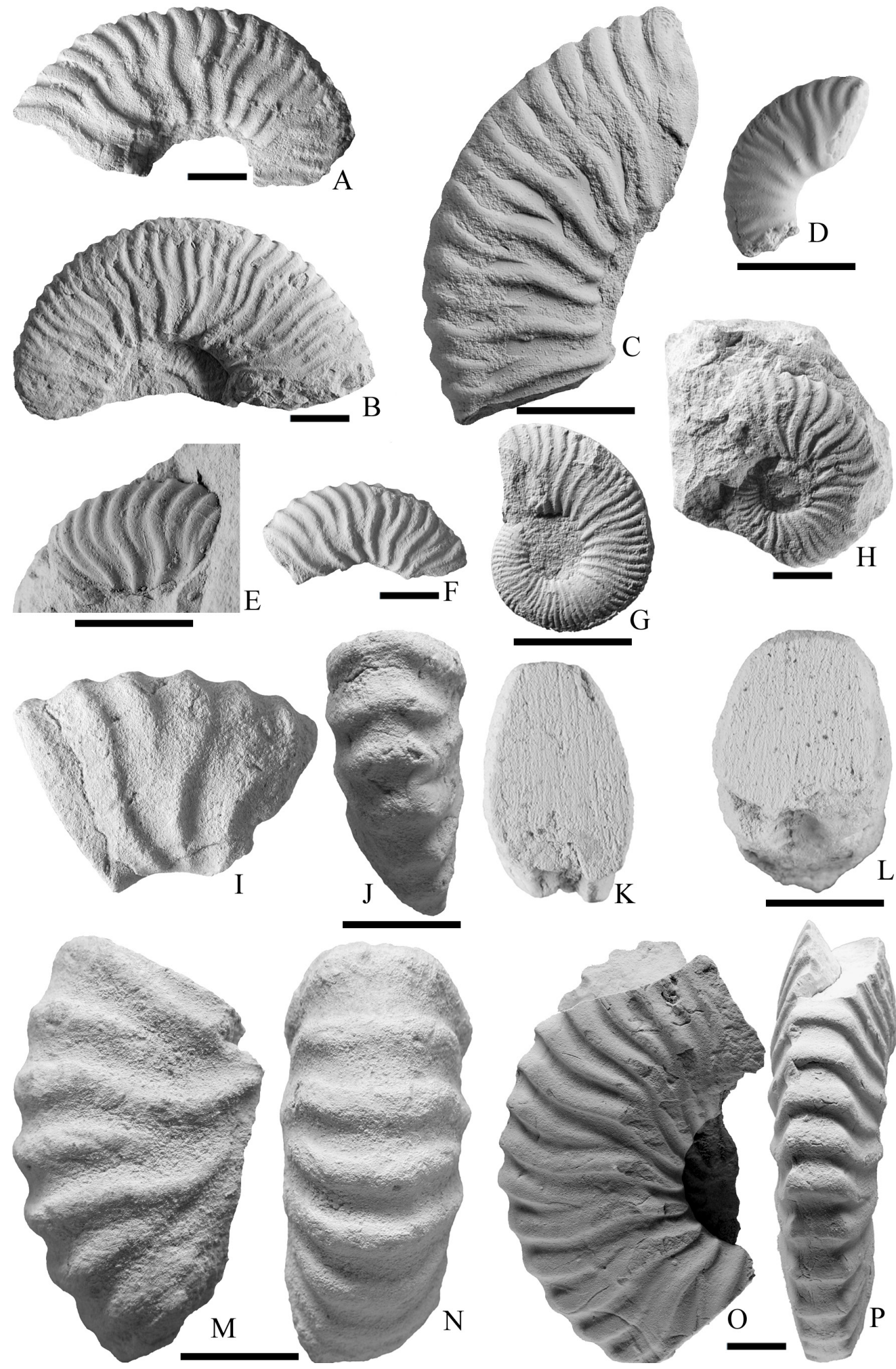

Fig. 6.- A: Deshayesites antiquus lateral view of the specimen PUAB 12535, Cap de Vinyet. B: Deshayesites luppovi lateral view of the specimen MV 900.1, Mas Segura section. C: Deshayesites forbesi lateral view of the specimen PUAB 88765, Cap de Vinyet section. D: Deshayesites forbesi lateral view of the specimen PUAB 48071, Tejería de Josa section. E: Deshayesites deshayesi lateral view of the specimen MV 425.2, Mola Murada section. F: Deshayesites deshayesi lateral view of the specimen MV 471.1, Todolella section. G: Deshayesites deshayesi lateral view of the specimen MV 425.1, Mola Murada section. H: Deshayesites vectensis lateral view of the specimen CPT-3599, Barranco de las Calzadas section. I-K: Dufrenoyia cf. furcata lateral, ventral and whorl section views of the specimen PUAB 88788, Mola de la Garumba. L-N: Dufrenoyia cf. furcata whorl section, lateral and ventral views of the specimen PUAB 88789, Mola de la Garumba. O-P: Dufrenoyia cf. justinae lateral and ventral views of the specimen CPT-3728, Barranco de las Calzadas section. Scale bar $=10 \mathrm{~mm}$. 


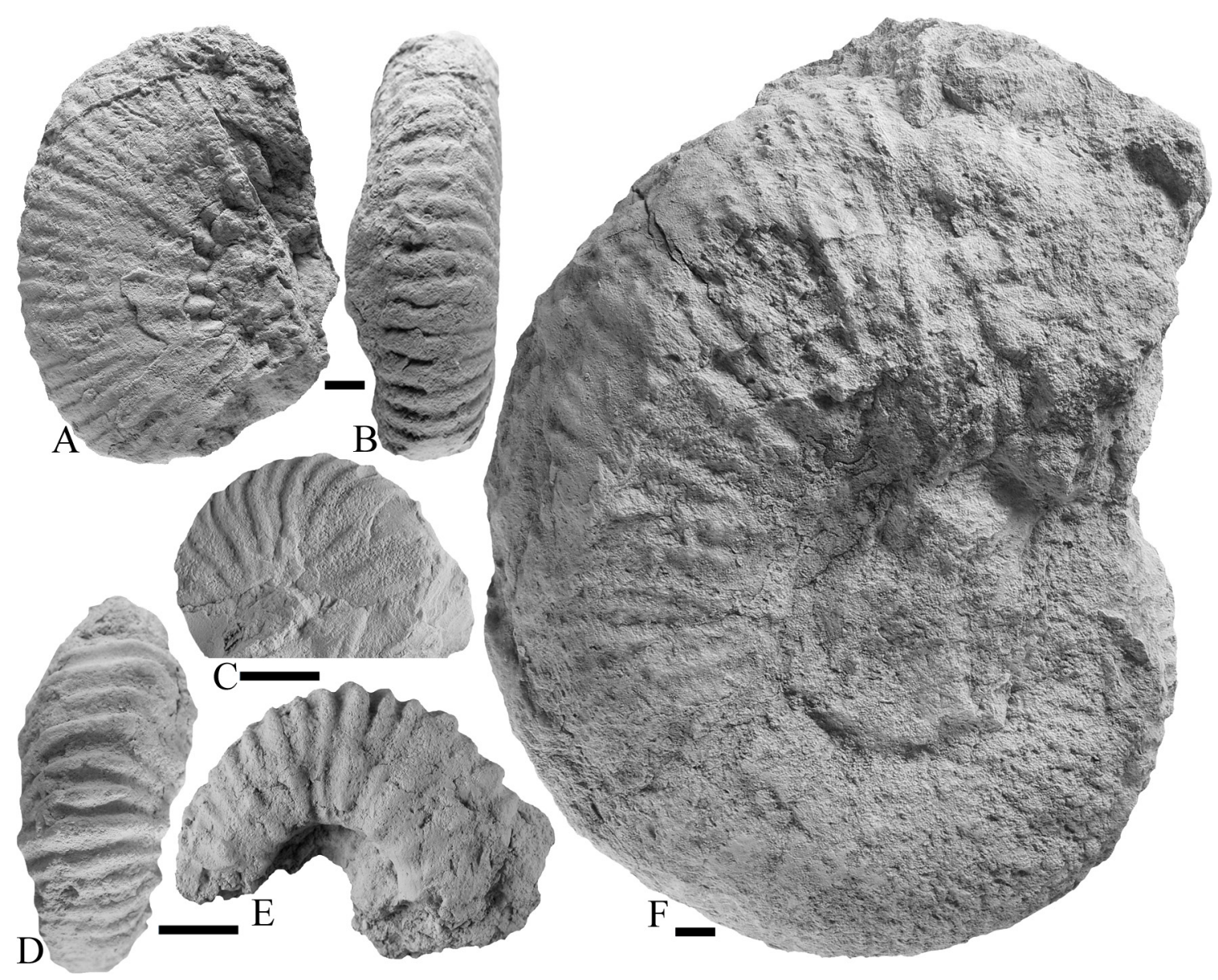

Fig. 7.- A-B: Parahoplites cf. vectensis lateral and ventral views of the specimen PUAB 68597, La Ferradura. C: Caseyella sp. lateral view of the specimen PUAB 68593, Cingle del Morral. D-E: Epicheloniceras sp. ventral and lateral views of the specimen PUAB 68596, Cingle del Morral. F: Parahoplites nutfieldiensis lateral view of the specimen PUAB 12307, Xodos. Scale bar=10 mm.

monoid Parahoplites maximus in the Oliete Sub-basin and Parahoplites nutfieldiensis in Xodos (Penyagolosa Sub-basin). Moreno-Bedmar et al. (2009b) recorded Parahoplites cf. vectensis in the Benicàssim-Orpesa area (Penyagolosa Sub-basin). The revision of ammonoids of this zone for the present work resulted in the following identifications: $\mathrm{Pa}$ rahoplites nutfieldiensis (Sowerby) (Fig. 7 F) from Xodos, Parahoplites cf. vectensis Casey (Fig. 7 A-B) from the Benicàssim-Orpesa area and Parahoplites sp. in the environs of the village of Benassal (Salzedella Sub-basin).

Acanthohoplites nolani Zone. Weisser (1959) described a specimen of Acanthohoplites bergeroni (Seunes) from Villaroya de los Pinares (Galve Sub-basin) and Martínez et al. (1994) reported the same taxon from the Oliete Sub-basin. We have not been able to revise these specimens or collect other ammonites from these sub-basins.

\subsection{Lower Albian}

The Albian ammonoid occurrences are essentially restricted to the environs of Traiguera (Salzedella Sub-basin) (Fig. 1). Canérot and Collignon (1981) first reported these ammonoids and ascribed them to the Upper Aptian. Later, Martínez et al. (1994) assigned the same record to the Lower Albian, and this age-attribution has been recently confirmed by Moreno-Bedmar et al. (2008).

Leymeriella tardefurcata Zone. Martínez et al. (1994) attributed the ammonoid record of the Traiguera area to the Douvilleiceras mammillatum Zone. However, they noted that some of the species could also be assigned to the Leymeriella tardefurcata Zone. This record was studied by MorenoBedmar et al. (2008), who confirmed that the lower part of the ammonoid record of Traiguera belongs to the Leymeriella tardefurcata Zone. This zone is represented by the species: Douvilleiceras gr. leightonense Casey (Fig. 8 D-E), Parengonoceras basei (Batalller), Parengonoceras cf. ebrayi (Loriol) (Fig. 8 C), Parengonoceras caneroti Collignon (Fig. 8 G, J), "Hypacanthoplites" sp. 1 (Fig. 8 A-B) and "Hypacanthoplites" sp. 2 (Fig. 8 F).

Douvilleiceras mammillatum Zone. Martínez et al. (1994) identified Douvilleiceras monile (Sowerby) in the Traiguera area and Douvilleiceras mammillatum (Schlotheim) (Fig. 8 $\mathrm{H}-\mathrm{I}$ ) in Benassal (Salzedella Sub-basin). We had access to these specimens and confirm these identifications. 

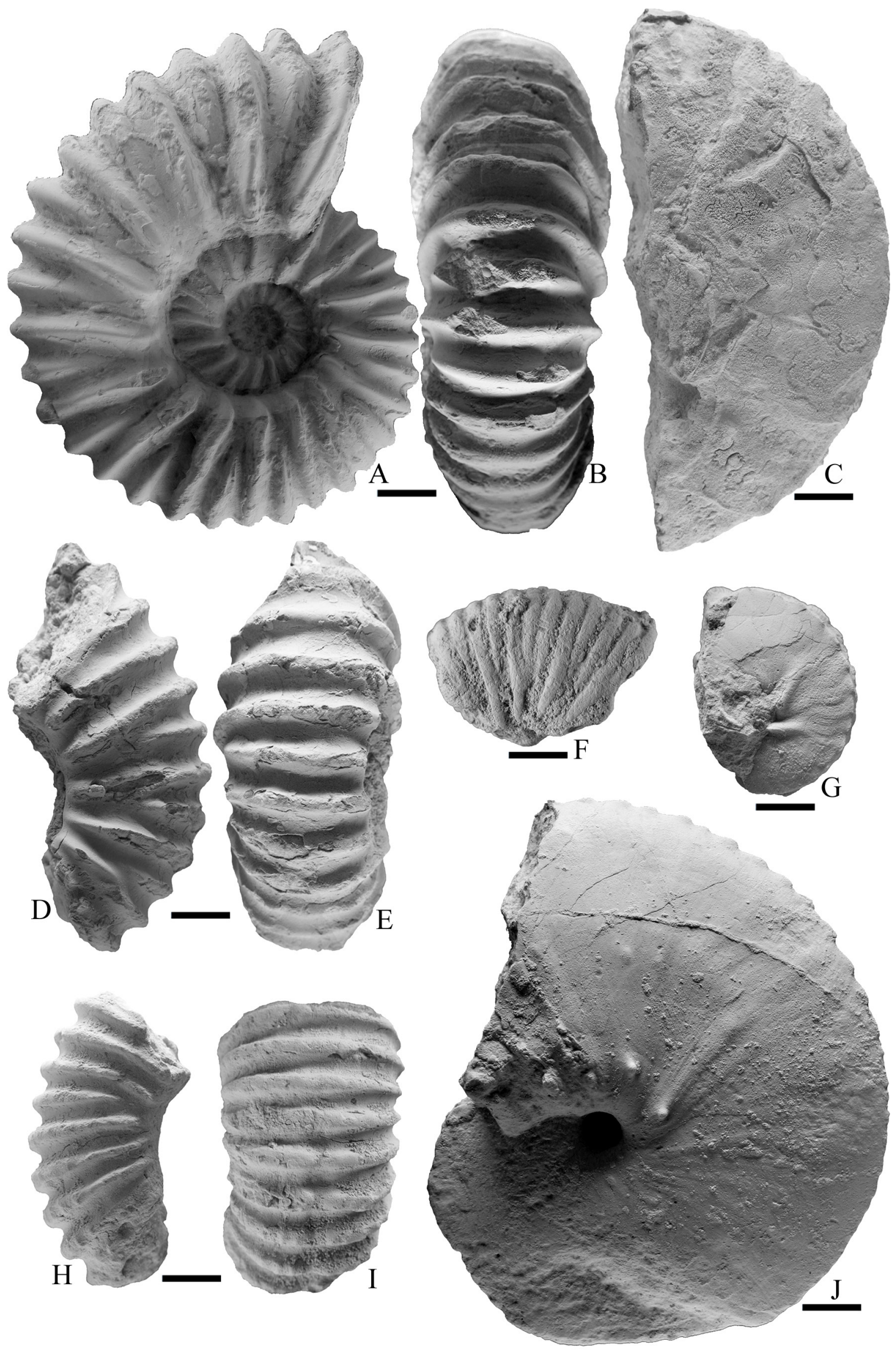

Fig. 8.- A-B: "Hypacanthoplites" sp.1 lateral and ventral views of the specimen RM 1, Traiguera. C: Parengonoceras cf. ebrayi lateral view of the specimen AC 10, Traiguera. D-E: Douvilleiceras gr. leightonense lateral and ventral wiews of the specimen AC 5, Traiguera. F: "Hypacanthoplites" sp.2 lateral view of the specimen AC 2, Traiguera. G: Parengonoceras caneroti lateral view of the specimen RM 2, Traiguera. H-I: Douvilleiceras mammillatum lateral view of the specimen MGSB 41829, Benassal. J: Parengonoceras caneroti lateral view of the specimen AC 3, Traiguera. Scale bar $=10 \mathrm{~mm}$. 
Fig. 9.- A-B: Engonhoplitoides cf. vicorpense lateral and ventral views of the specimen MGSB 55884, Arroyofrío. C: Engonhoplitoides $\mathrm{cf}$. vicorpense lateral view of the specimen MGSB 55886, Arroyofrío. Scale bar $=10 \mathrm{~mm}$.
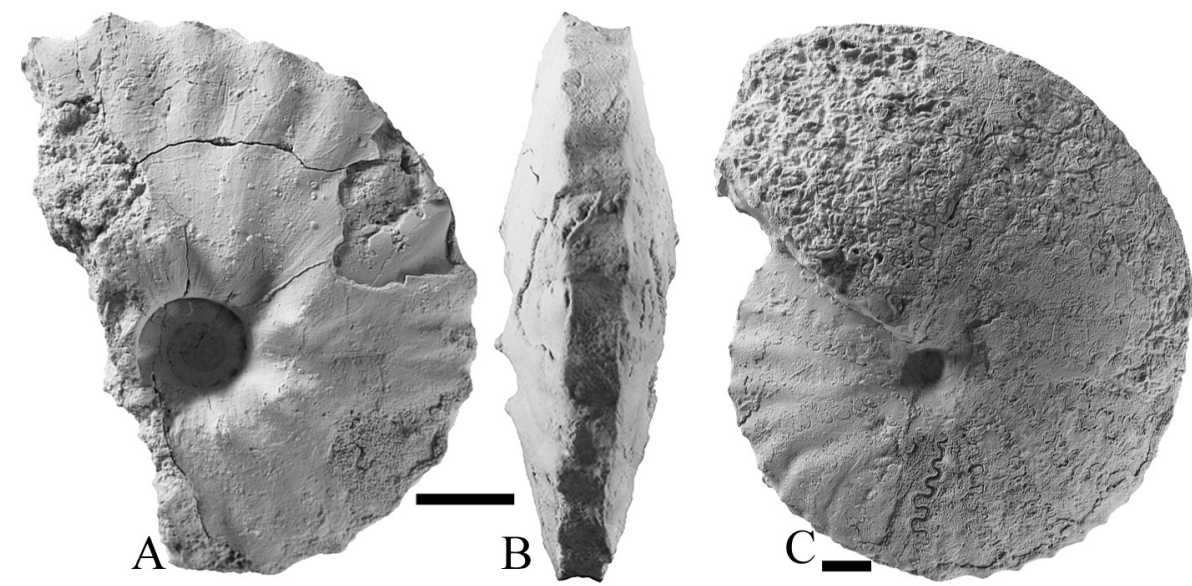

\section{Novel and relevant biostratigraphic considerations}

The La Gaita Formation (Fig. 2), which crops out in the Salzedella Sub-basin (Fig. 1), comprises the whole Hauterivian. The relative sea-level rose during the Late Valanginian to the Early Hauterivian, thus allowing the record of all of the Lower Hauterivian ammonite zones. During the Late Hauterivian, the relative sea-level remained low except in the middle part of the Pseudothumannia ohmi Zone, and it is thus the only ammonoid record that exists in the Upper Hauterivian of the Maestrat Basin. This age corresponds with the maximum flooding interval of the Ha6 global sequence of Handerbol et al. (1998) that it is associated with the Faraoni level (Company et al., 2005; Gradstein et al., 2004). This important transgression is recorded in the La Gaita Formation as a marly interval 10 to 20 meters thick that contains a well preserved pyritized ammonite record.

Argvethites sp. is the only ammonoid found in the Morella Formation. According to this, at least the lower and middle parts of the formation should be assigned to the Upper Barremian. This would support the hypothesis exposed by Moreno-Bedmar and Garcia (2011), who proposed that the Barremian-Aptian boundary is located in the basal part of the Forcall Formation. This proposal is based on the fact that the species Deshayesites antiquus Bogdanova and Deshayesites sp. cf. oglanlensis Bogdanova, which are characteristic of the lower part of the first Aptian ammonite zone (Deshayesites oglanlensis Zone), are found in the lower, non-basal part of the Forcall Formation. Moreno-Bedmar and García (2011) also compared the position of the Barremian-Aptian boundary with the Provençal Platform (France) and the Organyà Basin (Spain), both of which have a similar marine transgressive event starting in the uppermost Barremian. The basal marine transgressive deposits in both areas have an ammonoid record of the Pseudocrioceras genus that belongs to the uppermost Barremian. Unfortunately, to date no ammonoids have been found in the basal materials of the Forcall Formation and the possible position of the Barremian-Aptian boundary in the lower part of this formation remains only a plausible hypothesis at the present time. Moreover, the possibility that the ammonite collected within the Morella Formation by López Llorens (2007) corresponds to a reworked specimen should not be ruled out.

All of the Lower Aptian ammonite biozones are present in the Forcall Formation (Fig. 3). At least in the different subbasins, the Forcall Formation recorded the ammonoids during the maximum flooding interval of the Ap3 global sequence of the Handerbol et al. (1998) that is associated with the Oceanic Anoxic Event 1a (Bover-Arnal et al., 2010). This Lower Aptian record varies between the different sub-basins. For example, in the Oliete Sub-basin only one ammonoid zone is recorded while the Morella Sub-basin recorded the four zones. These differences depended on the depositional space available, which was controlled by the eustatic fluctuations and the local subsidence of each sub-basin.

In the Villarroya de los Pinares Formation, ammonoid occurrence was only reported from Las Mingachas locality (Galve Sub-basin). Specimens of Dufrenoyia sp. of the Dufrenoyia furcata Zone were found within a bed with a rudstone texture interpreted by Bover-Arnal et al. (2009) as a forced regressive wedge, and in the overlying slopes of a lowstand normal regressive carbonate platform (Bover-Arnal et al., 2009; 2012). Throughout the Maestrat Basin, the age of the Villarroya de los Pinares Formation ranges between the Deshayesites deshayesi and the Dufrenoyia furcata zones, but it is usually restricted to the middle part of the Dufrenoyia furcata Zone (Fig. 3).

The Benassal Formation recorded two large-scale transgressive-regressive sequences (Bover-Arnal et al., 2010). The ammonoids are present in the transgressive units, which are dominated by marls and marly limestones. The first transgresive unit corresponds to the Ap4 global sequence of Handerbol et al. (1998). This transgressive unit recorded two ammonite zones: the uppermost part of the Dufrenoyia furcata Zone and the Epicheloniceras martini Zone (Fig. 3). The basal beds of the Benassal Formation have been historically assigned to the Upper Aptian (Canérot et al., 1982; Salas, 1987; Bover-Arnal et al., 2010). However, in the Galve and 
the Morella sub-basins we recently assigned these beds to the uppermost part of the Lower Aptian, specifically to the uppermost part of the Dufrenoyia furcata Zone (Moreno-Bedmar, 2010; Moreno-Bedmar et al., 2011, 2012b; Bover-Arnal et $a l$. , in press). The second transgressive unit recorded the $\mathrm{Pa}$ rahoplites melchioris Zone (Martín-Martín et al., 2013). In the upper part of the Benassal Formation in the Galve and the Oliete sub-basins a significantly scarce ammonoid record of the Acanthohoplites nolani Zone is preserved. This biozone comprises the maximum flooding interval of the Ap5 global sequence of Handerbol et al. (1998). In the Oliete Sub-basin, the Dehesa Formation, which is a lateral equivalent of the Benassal Formation, contains the Parahoplites melchioris and Acanthohoplites nolani zones.

The occurrence of Lower Albian ammonoids in the lower part of the Escucha Formation is probably linked to the strong transgressions corresponding to the global sequences Ap6, Al1, Al2 and/or Al3 of Handerbol et al. (1998). The continental deposits of the middle and upper parts of the formation have been assigned to the upper part of the Lower Albian and the entire Middle Albian based on the palynological studies of Villanueva-Amadoz et al. (2010, 2011). The fluvial sandstones of the Utrillas Formation overlie the Escucha Formation. Above the Utrillas Formation an informal unit of green marls crops out, which mark the transition between the Utrillas Formation and the marine limestones and marls of the Mosqueruela Formation (Canérot et al., 1982). These Green Marls were studied by Villanueva-Amadoz et al. (2011) who assigned them to the uppermost Albian. In the Maestrat Basin no ammonoids were found in these marls. However, some ammonoids were collected by Geyer (1995a, b) in the Arroyofrío locality (Montes Universales de Albarracín, Teruel, South Iberian Basin). We reviewed these ammonoids for the present study and assigned them to the species Engonhoplitoides cf. vicorpense (Basse) (Fig. 9 A-C). Although the taxonomic and biostratigraphic knowledge of this taxon is poor, these ammonoids can be assigned without doubt to the Upper Albian. This is in agreement with the results by Villanueva-Amadoz et al. (2011).

\section{Conclusions}

The analysis of the stratigraphic distribution of ammonites in the Maestrat Basin allowed us to establish the faunal succession for the Lower Cretaceous (Hauterivian-Albian) in this region. We recognized the following zones: Acanthodiscus radiatus, Crioceratites loryi, Lyticoceras nodosoplicatum (Lower Hauterivian); Pseudothurmannia ohmi (Upper Hauterivian); Imerites giraudi (Upper Barremian); Deshayesites oglanlensis, Deshayesites forbesi, Deshayesites deshayesi, Dufrenoyia furcata (Lower Aptian); Epicheloniceras martini, Parahoplites melchioris, Acanthohoplites nolani (Upper Aptian); Leymeriella tardefurcata and Douvilleiceras mammillatum (Lower Albian). We also identified the following subzones: the Olcostephanus (Jeannoticeras) jeannoti in the upper half of the Crioceratites loryi Zone, the Deshayesites luppovi in the upper half of the Deshayesites oglanlensis Zone, the Roloboceras hambrovi in the upper half of the Deshayesites forbesi Zone, the Deshayesites grandis in the upper half of the Deshayesites deshayesi Zone and the twofold subdivision of the Dufrenoyia furcata Zone in two subzones, Dufrenoyia furcata and Dufrenoyia dufrenoyi.

Consequently, this study accurately determines the age of the lithostratigraphic units defined in this basin. In the lower part of the La Gaita Formation, we found recorded the three zones of the Lower Hauterivian. The uppermost part of this latter formation corresponds to the Pseudothurmania ohmi Zone. The Imerites giraudi Zone occurs in the Morella Formation. In the Forcall Formation, we found the four zones of the Lower Aptian. The ammonite record suggests that the base of this formation could be of Late Barremian age. The age of Villarroya de los Pinares Formation ranges, in different areas of the basin, from the Deshayesites deshayesi to the Dufrenoyia furcata Zones. The base of the Benassal Formation corresponds to the upper part of the Dufrenoyia furcata Zone in most parts of the Maestrat Basin. The rest of the Benassal Formation is Late Aptian in age. The lower part of the Escucha Formation recorded the two Lower Albian biozones.

\section{Acknowledgements}

This study was supported by the grants of the Swiss National Science Foundation (no. 20-121545), the Spanish Ministerio de Ciencia e Innovación $(\mathrm{I}+\mathrm{D}+\mathrm{i}$ research project CGL2008-04916), the Consolider-Ingenio 2010 programme, under CSD 2006-0004 "Topo-Iberia", the Grup Consolidat de Recerca "Geologia Sedimentària" (2009SGR-1451), the research project CGL2011-23759 and the research group RNM-178 (Junta de Andalucía). We are very grateful for the helpful reviews made by Peter F. Rawson and Kevin Page.

\section{References}

Aguado, R., Company, M., Sandoval, J., Tavera, J.M. (1997): Biostratigraphic events at the Barremian/Aptian boundary in the Betic Cordillera, southern Spain. Cretaceous Research, 18: 309-329.

Avram, E. (1999): The Deshayesites Kazansky, 1914 (ammonoidea) representatives in Romania, a link between the West-European and Caspian assemblages of this genus. In Oloriz, F., Rodrígez-Tovar, F.J. (Ed.), Advancing Research on Living and Fossil Cephalopods. Kluwer Academic/Plenum Publishers, New York: 437-462.

Cecca, F., Dhondt, A.V., Bogdanova, T.N. (1999): The Aptian stratigraphy of southern Tuarkyr (NW Turkmenistan, Central Asia). Revista Italiana di Paleontologia e Stratigrafia, 105, 3: 377-396.

Bover-Arnal, T., Salas, R., Moreno-Bedmar, J.A., Bitzer, K. (2009): Sequence stratigraphy and architecture of a late Early-Middle Aptian carbonate platform succession from the western Maestrat Basin (Iberian Chain, Spain). Sedimentary Geology, 219: 280-301. doi: 10.1016/j. sedgeo.2009.05.016

Bover-Arnal, T., Moreno-Bedmar, J.A., Salas, R., Skelton, P.W., Bitzer, K., Gili, E. (2010): Sedimentary evolution of an Aptian syn-rift carbonate system (Maestrat Basin, E Spain): effects of accommodation and environmental change. Geologica Acta, 8, 3: 249-280. 
doi:10.1344/105.000001533.

Bover-Arnal, T., Salas, R., Martín-Closas, C., Schlagintweit, F., Moreno-Bedmar, J.A. (2011): Expression of an Oceanic Anoxic Event in a neritic setting: Lower Aptian coral rubble deposits from the western Maestrat Basin (Iberian Chain, Spain). Palaios, 26: 18-32. doi:10.2110/palo.2010.p10-055r

Bover-Arnal, T., Löser, H., Moreno-Bedmar, J.A., Salas, R., Strasser, A. (2012): Corals on the slope (Aptian, Maestrat Basin, Spain). Cretaceous Research, 37: 43-64. doi:10.1016/j.cretres.2012.03.001.

Bover-Arnal T, Salas R, Guimerà J, Moreno-Bedmar J.A. Deep incision in an Aptian carbonate succession indicates major sea-level fall in the Cretaceous. Sedimentology. In press. doi: 10.1111/sed.12105.

Company, M., Aguado, R., Sandoval, J., Tavera, J.M., Jiménez de Cisneros, C., Vera, J.A. (2005): Biotic changes linked to a minor anoxic event (Faraoni Level, latest Hauterivian, Early Cretaceous). Palaeogeography, Palaeoclimatology, Palaeoecology, 224: 186-199. doi:10.1016/j.palaeo.2005.03.034

Canérot, J. (1974): Recherches géologiques aux confins des chaînes ibérique et catalane (Espagne). Trabajos de Tesis, Serie 5 (4). Enadimsa, Madrid, 520 p.

Canérot, J., Cuny, P., Pardo, G., Salas, R., Villena, J. (1982): Ibérica Central-Maestrazgo. In: Universidad Complutense de Madrid (ed.), El Cretácico de España: 273-344.

Coquand, H. (1865): Monographie paléontologique de l'étage Aptien de 1'Espagne. Mémoires de la Société d'Emulation de la Provence, 3: 17-411.

Delanoy, G. (1995): About some significant ammonites from the Lower Aptian (Bedoulian) of the Angles-Barrême area (South-East France). Memorie Descrittive della Carta Geologica d'Italia, 51: 65-101.

Delanoy, G. (1997): Biostratigraphie des faunes d'Ammonites à la limite Barrémien-Aptien dans la région d'Angles-Barrême-Castellane. Etude particulière de la famille des Heteroceratina Spath, 1922 (Ancyloceratina, Ammonoidea). Annales du Muséum d'Histoire $\mathrm{Na}$ turelle de Nice, 12: 1-270.

Delanoy, G., Moreno-Bedmar, J.A., Ruiz, J.J., Tolós Lládser, D. (2013): Xerticeras gen. nov., a new genus of micromorphic heteromorph ammonite (Ancyloceratina, Ancyloceratidae) from the lower Aptian of Spain.- Carnets de Géologie [Notebooks on Geology], Brest, Article 2013/02 (CG2013 A02), p. 89-103.

Dutour, Y. (2005): Biostratigraphie, évolution et renouvellements des ammonites de l'Aptien supérieur (Gargasien) du bassin vocontien (Sud-Est de la France). Unpublished doctoral thesis, Université Claude Bernard Lyon I, 302 p.

Geyer, O. F. (1995): Knemiceras uhligi (Choffat) dans la Chaîne Ibérique méridionale (Albien supérieur, Espagne). Batalleria, 5: 5-17.

Geyer, O. F. (1995): Zur Alb-Cenoman-Transgression im südlichen Keltiberikum (Spanien). Profil, 8: 473-482.

Gradstein, F.M., Ogg, J.G., Smith, A.G. (Eds.) (2004). A Geologic Time Scale. Cambridge University Press: 589 p.

Grauges, A., Moreno-Bedmar, J.A., Martínez, R. (2010): Desmocerátidos (Ammonoidea) del Aptiense Inferior (Cretácico Inferior) de la subcuenca de Oliete, Cordillera Ibérica Oriental (Teruel, España). Revista Española de Paleontología, 25, 1: 7-18.

Handerbol, J., Thierry J., Farley, M. B., Jacquin, T., Graciansky, P. C., Vail, P. (1998): Mesozoic and Cenozoic sequence chronostratigraphic framework of European basins, in P.C. Graciansky, et al. (ed) Mesozoic and Cenozoic Sequence Stratigraphy of European Basins. SEPM Special Publication 60, 3-13.

Hoedemaeker, Ph.J., Bulot, L. (1990): Preliminary ammonite zonation for the Lower Cretaceous of the Mediterranean Region. Géologie Alpine, 66: 123-127.

Hoedemaeker, Ph.J., Company M., (reporters), Aguirre-Urreta, M.B., Avram, E., Bogdanova, T.N., Bujtor, L., Bulot, L., Cecca, F., Delanoy,
G., Ettachfini, M., Memmi, L., Owen, H.G., Rawson, P.F., Sandoval, J., Tavera, J.M., Thieuloy, J.P., Tovbina, S.Z., Vasicek, Z. (1993): Ammonite zonation for the Lower Cretaceous of the Mediterranean region; basis for the stratigraphic correlation within IGCP-Project 262. Revista Espanola de Paleontologia, 8, 1: 117-120.

Hoedemaeker, Ph.J., Cecca, F., (reporters), Avram, E., Company, M., Delanoy, G., Erba, E., Ettachfini, M., Faraoni, P., Kakabadze, M.V., Landra, G., Marini, A., Memmi, L., Pallini, G., Rawson, P.F., Ropolo, P., Sandoval, J., Tavera, J.M., Vasicek, Z. (1995): Report on the $3^{\text {rd }}$ International Workshop on the Standard Lower Cretaceous Ammonite Zonation of the Mediterranean Region. Memorie Descrittive della Carta Geologica d'Italia, 51: 213-215.

Hoedemaeker, Ph.J., Rawson, P.F. (2000): Report on the 5th International Workshop of the Lower Cretaceous Cephalopod Team (Vienna, 5 September 2000). Cretaceous Research, 21: 857-860. doi:10.1006/ cres.2000.0233.

Hoedemaeker, Ph.J., Reboulet, S., (reporters), Aguirre-Urreta, M.B., Alsen, P., Aoutem, M., Atrops, F., Barragan, R., Company, M., González Arreola, C., Klein, J., Lukeneder, A., Ploch, I., Raisossadat, N., Rawson, P.F., Ropolo, P., Vašiček, Z., Vermeulen, J., Wippich M.G.E. (2003): Report on the 1st International Workshop of the IUGS Lower Cretaceous Ammonite Working Group, the 'Kilian Group' (Lyon, 11 July 2002). Cretaceous Research, 24: 89-94. doi:10.1016/ S0195-6671(03)00018-1

López Llorens, J. (2007): Hallazgo de Imerites giraudi giraudi, ammonítido barremiense, en las "Arcillas de Morella". Consecuencias. Batalleria, 13: 53-56.

Marin, P., Sornay, J. (1971): Précisions sur l'âge des formations aptiennes aux confins de l'Aragón et du Maestrazgo (Provinces de Teruel et Castellón de la Plana, Espagne). Comptes Rendus sommaires de la Société géologique de France, 3: 165-167.

Martín-Martín, J.D.; Gomez-Rivas, E.; Bover-Arnal, T.; Travé, A.; Salas, R.; Moreno-Bedmar, J.A.; Tomás, S.; Corbella, M.; Teixell, A.; Vergés, J.; Stafford, S.L. (2013): The Upper Aptian to Lower Albian syn-rift carbonate succession of the southern Maestrat Basin (Spain): Facies architecture and fault-controlled stratabound dolostones. Cretaceous Research, 41: 217-236. doi: 10.1016/j.cretres.2012.12.008

Martínez, R., Grauges, A., Salas, R. (1994): Distribución de los ammonites del Cretácico inferior de la Cordillera Costera Catalana e Ibérica Oriental. Cuadernos de Geología ibérica, 18 : 337-354.

Moreno, J.A., Company, M., Tomás. S. (2007): Ammonoideos del Hauteriviense inferior de Torre Endoménech (Castellón). Batalleria, 13: 65-68.

Moreno-Bedmar, J.A., Bulot, L., Latil, J.L., Martínez, R., Ferrer, O., Bover-Arnal, T., Salas, R. (2008): Precisiones sobre la edad de la base de la Fm. Escucha, mediante ammonoideos, en la subcuenca de la Salzedella, Cuenca del Maestrat (E Cordillera Ibérica). Geo-Temas, 10: 1269-1272.

Moreno-Bedmar, J.A., Company, M., Bover-Arnal, T., Salas, R., Delanoy, G., Martínez, R., Grauges, A. (2009a): Biostratigraphic characterization by means of ammonoids of the lower Aptian Oceanic Anoxic Event (OAE 1a) in the eastern Iberian Chain (Maestrat Basin, eastern Spain). Cretaceous Research, 30: 864-872. doi:10.1016/j.cretres.2009.02.004

Moreno-Bedmar, J.A., Company, M., Barragán, R., Salas, R., MartínMartín, J.D., Bover-Arnal, T., Gomez-Rivas, E. (2009b): Precisiones, mediante ammonoideos, sobre la edad de la Fm. Benassal, Cuenca del Maestrat (Cadena Ibérica). XXV Jornadas de la Sociedad Española de Paleontología. Libro de Resúmenes, Palmqvist y J.A. Pérez-Claros, Coords. Universidad de Málaga. 231-234.

Moreno-Bedmar, J.A. (2010): Ammonits de l'Aptià inferior de la península Ibèrica. Biostratigrafia i aportacions a l'estudi del Oceanic Anoxic Event 1a. Doctoral Thesis, Universitat de Barcelona, Barcelona, $331 \mathrm{p}$. 
Moreno-Bedmar, J.A., Company, M., Bover-Arnal, T., Salas, R., Delanoy, G., Maurrasse, F.J.-M.R., Grauges, A., Martínez, R. (2010a): Lower Aptian ammonite biostratigraphy in the Maestrat Basin (Eastern Iberian Chain, Eastern Spain). A Tethyan transgressive record enhanced by synrift subsidence. Geologica Acta, 8, 3: 281-299. doi:10.1344/105.000001534

Moreno-Bedmar, J.A., Garcia, R., Salas, R., Ferrer, O. (2010b): Bioestratigrafía de los ammonites del Aptiense inferior (Cretácico Inferior) del Perelló (Tarragona). In: Moreno-Azanza, M., Díaz-Martínez, I., Gasca, J.M., Melero-Rubio, M., Rabal-Garcés, R., Sauqué, V. (ed). VIII Encuentro de Jóvenes Investigadores en Paleontología, volumen de actas, Cidaris, 30: 201-204.

Moreno-Bedmar, J.A., Garcia, R. (2011): Análisis bioestratigráfico de los ammonoideos del Aptiense inferior (Cretácico Inferior) del Miembro Cap de Vinyet (Formación Margas del Forcall) de la subcuenca de Morella (Castellón). Consideraciones sobre el límite BarremienseAptiense. In: Pérez-García, A., Gascó, F., Gasulla, J.M., Escaso, F. (ed.), Viajando a Mundos Pretéritos. Ayuntamiento de Morella, Morella, Castellón: 215-222.

Moreno-Bedmar, J.A., Bover-Arnal, T., Barragán, R., Salas, R. (2011): La transgresión tetisiana del Aptiense inferior terminal: comparación entre su registro en México y España y relación con el ciclo global de tercer orden Ap4. Paleontologia i Evolució Memòria especial, 5: 259-262.

Moreno-Bedmar, J.A., Company, M., Sandoval, J., Tavera, J.M., BoverArnal, T., Salas, R., Delanoy, G., Maurrasse, F.J.-M.R., Martínez, R. (2012a): Lower Aptian ammonite and carbon isotope stratigraphy in the eastern Prebetic Domain (Betic Cordillera, southeastern Spain). Geologica Acta, 10, 4: 1-12. doi:10.1344/105.000001752

Moreno-Bedmar, J.A., Bover-Arnal, T., Barragán, R., Salas, R. (2012b): Uppermost Lower Aptian transgressive records in Mexico and Spain: chronostratigraphic implications for the Tethyan sequences. Terra Nova, 24: 333-338. doi:10.1111/j.1365-3121.2012.01069.x

Najarro, M., Rosales, I., Moreno-Bedmar, J.A., de Gea, G.A., Barrón, E., Company, M., Delanoy, G. (2011): High-resolution chemo- and biostratigraphic records of the Early Aptian oceanic anoxic event in Cantabria (N Spain): Palaeoceanographic and palaeoclimatic implications. Palaeogeography, Palaeoclimatology, Palaeoecology, 299: 137-158. doi:10.1016/j.palaeo.2010.10.042

Neumann, C. (1987): Le Crétacé Inférieur (Hauterivien-Albien) du Maestrazgo Meridional (Espagne): un exemple d'une plate-forme carbonatée en régime distensif. Doctoral Thesis, Université Paul Sabatier, Tolouse, $377 \mathrm{p}$.

Rawson, P.F., Hoedemaeker, P.J., (Reporters), Aguirre-Urreta, M.B., Avram, E., Ettachfini, M., Kelly, S.R.A., Klein, J., Kotetishvili, E., Owen, H.G., Ropolo, P., Thomson, M.R.A., Wippich, M., Vašíček, Z. (1999): Report on the 4th International Workshop of the Lower Cretaceous Cephalopod Team (IGCP-Project 362). Scripta Geologica, Special Issue 3: 3-13.

Reboulet, S., Hoedemaeker, P.J., (reporters), Aguirre-Urreta, M.B., Alsen, P., Atrops, F., Baraboshkin, E.Y., Company, M., Delanoy, G., Dutour, Y., Klein, J., Latil, J.L., Lukeneder, A., Mitta, V., Mourgues, F.A., Ploch, I., Raisossadat, N., Ropolo, P., Sandoval, J., Tavera, J.M., Vasicek, Z., Vermeulen, J. (2006): Report on the 2nd international meeting of the IUGS lower Cretaceous ammonite working group, the "Kilian Group" (Neuchâtel, Switzerland, 8 September 2005). Cretaceous Research, 27: 712-715. doi:10.1016/j.cretres.2006.03.006

Reboulet, S., Klein, J., (reporters), Barragán, R., Company, M., González-Arreola, C., Lukeneder, A., Raisossadat, S.N., Sandoval, J.,
Szives, O., Tavera, J.M., Vašíček, Z., Vermeulen, J. (2009): Report on the 3rd International Meeting of the IUGS Lower Cretaceous Ammonite Working Group, the "Kilian Group" (Vienna, Austria, 15th April 2008). Cretaceous Research, 30: 496-502. doi:10.1016/j.cretres.2008.12.009

Reboulet, S., Rawson, P.F., Moreno-Bedmar, J.A., Aguirre-Urreta, M.B., Barragán, R., Bogomolov, Y., Company, M., González-Arreola, C., Stoyanova, V.I., Lukeneder, A., Matrion, B., Mitta, V., Randrianaly, H., Vašiček, Z., Baraboshkin, E.J., Bert, D., Bersac, S., Bogdanova, T.N., Bulot, L.G., Latil, J.-L., Mikhailova, I.A., Ropolo, P., Szives, O. (2011): Report on the 4th International Meeting of the IUGS Lower Cretaceous Ammonite Working Group, the "Kilian Group" (Dijon, France, 30th August 2010). Cretaceous Research, 32: 786-793. doi:10.1016/j.cretres.2011.05.007

Ropolo, P., Gonnet, R., Conte, G. (1999): The "Pseudocrioceras interval" and adjacent beds at La Bédoule (SE France): implications to highest Barremian/lowest Aptian biostratigraphy. Scripta Geologica, Special Issue 3: 159-213.

Ropolo, P., Conte, G., Gonnet, R., Masse, J.-P., Moullade, M. (2000): Les faunes d'Ammonites du Barrémien supérieur/Aptien inférieur (Bédoulien) dans la région stratotypique de Cassis-La Bédoule (SE France): état des connaissances et propositions pour une zonation par Ammonites du Bédoulien-type. Géologie Méditerranéenne, 25 (1998): 167-175.

Salas, R. (1987): El Malm i el Cretaci inferior entre el Massís de Garraf $i$ la Serra d'Espadà. Doctoral Thesis, Universitat de Barcelona, Barcelona, $345 \mathrm{p}$.

Salas, R., Casas, A. (1993): Mesozoic extensional tectonics, stratigraphy, and crustal evolution during the Alpine cycle of the eastern Iberian Basin. Tectonophysics, 228: 33-55.

Salas, R., Guimerà, J. (1996): Rasgos estructurales principales de la cuenca cretácica inferior del Maestrazgo (Cordillera Ibérica oriental). Geogaceta, 20: 1704-1706.

Salas, R., Guimerà, J., Mas, R., Martín-Closas, C., Meléndez, A., Alonso, A. (2001): Evolution of the Mesozoic Central Iberian Rift System and its Cainozoic inversion (Iberian Chain). In: Ziegler, P.A., Cavazza, W., Robertson, A.H.F., Crasquin-Soleau, S. (ed.), Peri-Tethys Memoir 6: Peri-Tethyan Rift/Wrench Basins and Passive Margins. Mémoires du Muséum National d'Histoire Naturelle 186, Paris: 145-186.

Skelton, P.W., Gili, E., Bover-Arnal, T., Salas, R., Moreno-Bedmar, J.A. (2010): A New Species of Polyconites from the Lower Aptian of Iberia and the Early Evolution of polyconitid Rudists. Turkish Journal of Earth Sciences, 19: 557-572. doi:10.3906/yer-0901-7

Tomás, S. (2007): Sistemas arrecifales del Cretácico inferior de la Cuenca del Maestrat. Modelos deposicionales, paleontológicos y diagenéticos. Doctoral Thesis, Universitat de Barcelona, Barcelona, 192 p.

Vilanova, J. (1859): Memoria geognóstica-agrícola sobre la provincia de Castellón. Real Academia de Ciencias: 229 p.

Villanueva-Amadoz, U., Pons, D., Diez, J. B., Ferrer, J., Sender, L.M. (2010) : Angiosperm pollen grains of Sant Just site (Escucha Formation) from the Albian of the Iberian Range (north-eastern Spain). Review of Palaeobotany and Palynology, 162: 362-381. doi :10.1016/j. revpalbo.2010.02.014

Villanueva-Amadoz, U., Sender, L.M., Diez, J.B., Ferrer, J., Pons, D. (2011): Palynological studies of the boundary marls unit (Albian-Cenomanian) from northeastern Spain. Paleophytogeographical implications. Geodiversitas, 33, 1: 137-176. doi:10.5252/g2011n1a7

Weisser, D. (1959): Acerca de la estratigrafía del Urgo-Aptense en las cadenas Celtibericas de España. Notas y Comunicaciones del Instituto Geológico y Minero de España, 55: 17-32. 